
Spinach in Storage

\title{
Oladele* and Oluwole Olakunle
}

Department of Biology Federal University of Technology, P.M.B 704, Akure, Nigeria

\begin{abstract}
This work investigated microorganisms associated with the deterioration of fresh leafy Indian spinach. Microbial counts involve the use of pour plate method (PPM). The deterioration, marked by loss of green colour to mushiness of the spinach leaves was caused by a total of four (4) bacterial species and five (5) fungal species. The bacteria isolates were Bacillus subtilis, Serratia marcescens, Lactobacillus $s p$, and Proteus mirabilis. The fungal isolates were Aspergillus niger, Aspergillus flavus, Mucor mucedo, Fusarium oxysporum and Penicillium sp. The spinach had high moisture content ranging from $90.50 \%$ in the white variety (Basella alba) and $90.00 \%$ in the purple variety (Basella rubra). The presence of these microorganisms in the leafy spinach indicated microbial contamination, hence spoilage and loss of quality.
\end{abstract}

Keywords: Deterioration; Spoilage; Contamination; Indian spinach

\section{Introduction}

Indian spinach was described as a highly succulent vegetable similar to waterleaf [1]. It belongs to the family basellaceae. The name for spinach is derived from the perison word "ispanai" which means "greenhand" and which later became "spanachia" (Latin), to spinach in English Language [2], of the many spinach cultivars, Indian spinach is the most cultivated in Africa [3]. This is probably due to good environmental factors such as high temperature conditions, high rainfall and moist fertile soils with high organic matter observed in the African continent. The vegetable is cultivated for the use of its leaves and therefore used for soup or stew making. It contains large amounts of ascorbic acid and very rich in mineral substances [3]. In fact, according to Marjorie [5], a serving of 100 grams of Indian Spinach gives 3.2grams of protein, 4.3grams of carbohydrates and 0.3grams of fat together with various proportions of difference mineral elements. Basella alba and Basella rubra were reported as the two major species of Indian spinach in Africa with the former having green stems and green leaves while the latter has purple stems and purple leaves [3]. Spoilage of green leafy vegetable is due to the activity of microorganisms, the condition favourable for their proliferation being moisture and warmth [6].

Eboh and Okoh [6] has worked on microorganisms associated with some common vegetables in Nigeria excluding Basella species. Moreso, Adebayo [7] has equally worked on proximate composition and microbial spoilage of six selected leafy vegetables in South West, Nigeria in which Basella species was excluded out of his research work. Research programmes on leafy vegetables in Nigeria cover only the routinely cultivated ones such as Amaranthus sp (L.), Solanum macrocarpon (L), Celosia argentia (L.), Corchorus Oitorius (L), Telfairia occidentalis (F.), Hooks and Hibiscus sabdarifa (L.) [8]. So, there is dearth of information on the spinach vis-à-vis its spoilage and microbes associated with its deterioration. This study therefore, focuses on microorganims associated with the deterioration of fresh leafy Indian Spinach in storage.

\section{Materials and Methods}

\section{Sources of sample}

Two species of Basella namely Basella alba and Basella rubra were self - cultivated and hand harvested 90 days after planting. Before use, the fresh leaves were selected for uniformity of colour, smoothness, maturity based on size and kept unpreserved and unprocessed in polyethylene bags for 3 days before investigation. The leaves were stored in the bags according to their species type under ambient storage conditions.

\section{Culture media}

The culture media used for the isolation of bacteria was nutrient agar (oxoid) while potato dextrose agar (oxoid) used for the isolation of fungi was acidified with $1 \%$ lactic acid. The culture media used was made by Lab M Limited Topley House, 52 Washlane, Bury, Lancashire BLA 6 AS, United Kingdom.

\section{Microbiological analyses}

Microbial isolation and count carried out on the leafy samples by serial dilution plate method. The leafy samples randomly selected from each bag was immersed in sterile water and serially diluted to $\mathrm{X} 10^{-3}$ dilution factor. The $\mathrm{X} 10^{-3}$ dilution was plated in the respective media in triplicates using pour-plate technique for both enumeration and isolation. The isolates were subcultured to obtain pure cultures. The plates were incubated at $30^{\circ} \mathrm{C}$ for 24 hours and 72 hours for bacteria and fungi respectively. The bacterial isolate was identified using morphological and biochemical characteristics [9]. The moulds were identified using microscopy and cultural characteristics using the text of Frazier and Westhoff [10] and Alexopolus and Mims [11].

\section{Moisture content determination}

The moisture contents of the selected freshly harvested samples were carried out using the oven method. Each test sample was weighed accurately into standard dishes of known weights with tight fitting lids. The open dishes containing the samples were placed in oven at $105^{\circ} \mathrm{C}$

*Corresponding author: Oladele, Department of Biology Federal University of Technology, P.M.B 704, Akure, Nigeria, E-mail: richcometh2003@yahoo.com

Received September 02, 2011; Accepted October 24, 2011; Published October 26, 2011

Citation: Oladele, Olakunle O (2011) Microorganisms Associated with the Deterioration of Fresh Leafy Indian Spinach in Storage. J Plant Pathol Microbio 2:110. doi:10.4172/2157-7471.1000110

Copyright: @ 2011 Oladele, et al. This is an open-access article distributed under the terms of the Creative Commons Attribution License, which permits unrestricted use, distribution, and reproduction in any medium, provided the original author and source are credited. 
Citation: Oladele, Olakunle O (2011) Microorganisms Associated with the Deterioration of Fresh Leafy Indian Spinach in Storage. J Plant Pathol Microbiol 2:110. doi:10.4172/2157-7471.1000110

Page 2 of 3

for 5hrs [12]. The dishes were then removed, covered with lids and allowed to cool in a dessicator before they were weighed to obtain the final weight. This was done in triplicates.

The moisture content of the test sample was then calculated as follows:

$\%$ Moisture content $=\frac{\text { Weight before drying }- \text { Weight after drying }}{\text { Weight before drying }} \times 100$

\section{Discussion}

Table 1 showed the occurrence of bacteria and fungi on the deteriorated leafy spinach. The deterioration according to this work was evident by loss of green colour to mushiness of the leaves and very high microbial count. This is in agreement with the work of Kendal et al. [13] who reported loss of green pigments as a post harvest deterioration of leafy vegetables and microorganisms as agent of deterioration. Hence, the microbial isolates are implicated in the colour change of the leaves.

The various bacteria isolates associated with the deteriorated leafy spinach samples were Bacillus subtilis, Serratia marcescents, Lactobacillus sp and Proteus mirabilis while the fungal isolates included Aspergillus niger, Mucor mucedo, Aspergillus flavus and Fusarium oxysporum (Table 1). This agrees with reports of Anon [14] that growth and activity of microorganisms principally bacteria and fungi is one of the major causes of deterioration of leafy vegetables. The work of Eboh and Okoh [6] reported Fusarium sp, Aspergillus flavus, Aspergillus niger and Mucor sp as the organisms found associated with decayed leafy vegatables. So, the deterioration of the leafy spinach samples is not unconnected with these isolates.

All the bacterial and fungal isolates were found on both species of the spinach. Table 2 showed the total viable bacterial and fungal count of the spinach samples. The high total viable bacteria and fungal counts in the two species may not be unconnected with the high moisture contents of the spinach (Table 3 ) and moreso, that the vegetable is especially rich in vitamins and mineral substances. This validates the reports of Anon [14] that microbes grow in an environment of high

\begin{tabular}{|l|l|l|}
\hline Microbial isolates & $\begin{array}{l}\text { Frequency of occurrence in } \\
\text { leafy spinach samples }\end{array}$ & \\
\hline Bacteria & Basella alba & Basella rubra \\
\hline Staphylocossus aureus & + & + \\
\hline Bacillus Subtilis & + & + \\
\hline Lactobacillus sp & + & + \\
\hline Serratia marcescens & + & + \\
\hline Proteus mirabilis & + & + \\
\hline Fungi & + & + \\
\hline Aspergillus niger & + & + \\
\hline Mucor mucedo & + & + \\
\hline Aspergillus flavus & + & + \\
\hline Fusarium oxysporum & + & + \\
\hline Penicillium sp & + & + \\
\hline + = Present & & \\
\hline - Absent & & \\
\hline
\end{tabular}

Table 1: Frequency of Occurrence of Microbial Isolates of the spinach samples.

\begin{tabular}{|l|l|l|}
\hline Samples & $\begin{array}{l}\text { Total viable bacterial count } \\
\text { (cfu/g) }\end{array}$ & $\begin{array}{l}\text { Fungal count per gram } \\
\text { (cfu/g) }\end{array}$ \\
\hline Basella alba & $8.8 \times 10^{6}$ & $4.0 \times 10^{1}$ \\
\hline $\begin{array}{l}\text { Basella } \\
\text { rubra }\end{array}$ & $9.2 \times 10^{6}$ & $5.0 \times 10^{1}$ \\
\hline
\end{tabular}

$\mathrm{Cfu} / \mathrm{g}=$ colony forming unity per gram

Table 2: Microbial counts of the spinach samples.

\begin{tabular}{|l|l|}
\hline Samples & Percentage (\%) Moisture content \\
\hline Basella alba & $90.50 \pm 0.00$ \\
\hline Basella rubra & $90.00 \pm 0.00$ \\
\hline
\end{tabular}

Values for moisture content are means of three replicates \pm standard deviation of the mean

Table 3: Moisture content of the fresh leafy Indian Spinach.

moisture contents and nutrients. Thus, the high moisture contents of the Basella species coupled with its richness in minerals and vitamins must have encouraged the growth of this microbe on the spinach leading to its deterioration.

The emergence of the fungal isolates on the spinach samples no doubt suggests possible contaminations by spores in the air, since their spores are numerously available in the air [15]. The isolation of Staphylococcus aureus is indicative of human contamination during handling, since the microbe is known to be a normal flora of man (Onuorah et al, 1987). The presence of Bacillus subtilis, Serratia marcescens, Lactobacillus sp and Proteus mirabilis on the deteriorated spinach samples may be linked to the fact that these microbes are widely distributed in air, dusts and soils.

The high incidence of microorganisms in the spinach samples after the 3-day storage suggests spoilage and loss of eating quality of the spinach. This is in conformity with the reports of Kendall [16] that spinach could only be stored after harvest for one to two days in order to keep its eating quality, otherwise it would perish very quickly. However, the vegetable (Basella species) can be stored for a long time or has longer shelf life if preserved.

\section{Acknowledgement}

My foremost gratitude goes to the most High God for His mercy, wisdom, intervention and provision. In the same vein, sincere gratitude also goes to Dr. (Mrs.) A.T. Aborisade whose advice, kindness, gentle and thorough but intelligent correction and editing have immensely contributed towards the successfu completion of this work. Lack of space and time will fail me to keep mentioning names. However, I deeply appreciate every contribution made by every individual in converting this research work into paper work, thus contributing my own quota to scientific knowledge.

\section{References}

1. Harry AM (2000) Edible leaves. Proceeding of the workshop on edible leaves at Department of Horticulture, University of Georgia, Georgia, 83-85.

2. Sofos JH (2003) Drying vegetables Proceedings of the workshop on drying of leafy Vegatables at University of Goergia, Goergia, 4-10.

3. Procher MH, Ken F, Facciola SY (1995) Plant for a future land care system Research laboratory publication. Department of Crop production, Institute of Land and Food Resources, The University of Melbourne, Australia, 1-5.

4. Yoon OC (2004) Processing leafy vegetables. Journal of Food Technology 40: 12-15.

5. Margorie M (2003) Nutritional value of dried leafy vegetable. Journal of Food Technology 39: 5-15.

6. Eboh DO, Okoh Cl (1980) A preliminary Taxonomic study of fungi Associated with some vegetables in Nigeria. Nigeria Journal of Agric Science 2: 10-12.

7. Adeboye OC (1996) Proximate Composition and Nutrient Analysis of six selected leafy vegetables of Southwest Nigeria. Ife Journal of Agriculture 18 56-59.

8. Nihort (2008) Nigeria Edible Leafy vegetables. National Institute for Horticultural Research and Training Annual Report. 48.

9. Buchanan RE, Gibbons NE (1974) Bergey's Manual for Determinative Bacteriology. (Eight Edition), William and Wilkings company, Baltimore.

10. Frazier WC, Westhoff DC (1978) Food microbiology (3 $3^{\text {rd }}$ Edition), Mc Graw-Hil Book company, New York, 540 . 
Citation: Oladele, Olakunle O (2011) Microorganisms Associated with the Deterioration of Fresh Leafy Indian Spinach in Storage. J Plant Pathol Microbiol 2:110. doi:10.4172/2157-7471.1000110

11. Alexopolus CJ, Mims CW (1988) Introductory Mycology. Third Edition. Wiley Eastern Limited, 102

12. AOAC (1990) Official method of Analysis. Association of official Analytical chemist. (15 ${ }^{\text {th }}$ Edition), Washington DC, 440.

13. Kendall PA, Yoon V, Sofos JN (2004) Inactivation of Salmonelia during drying and storage of Nantes Carrot slices treated with steam, water or acid blanching before dehydration. A proceeding of International Association of Food protection Annual meeting.
14. Anon (1995) Fruit and Vegetable Processing. Food and Agriculture organization of the United Nations, Rome. 22: 13-15.

15. Arotupin DJ, Akinyosoye FA, Oladele OO (2003) Microbial quality of selected commercially packaged chocolately Beverages in Akure - Nigeria. Journal of Nigerian society for Experimental Biology 3: 35-41

16. Kendall PA (2002) Inactivation of Salmonella during and storage of Indian spinach treated with steam, water or acid blanching before dehydration. American Journal of Food protection 87: 12-15. 